\title{
AVALIAÇÃO QUALITATIVA DOS SERVIÇOS ECOSSISTÊMICOS OFERECIDOS PELAS PRAIAS DA APA LAGOA ENCANTADA/RIO ALMADA, BAHIA, BRASIL
}

\author{
José Rodrigues de Souza Filho \\ Instituto Federal Baiano, Programa de Pós-Graduação em Educação Profissional e Tecnológica, BA, Brasil \\ irsouzageografia@gmail.com \\ Iracema Reimão Silva \\ Universidade Federal da Bahia, Instituto de Geociências, Salvador, BA, Brasil \\ iracemars@yahoo.com.br
}

Fábio Carvalho Nunes

Instituto Federal Baiano, Programa de Pós-Graduação em Educação Profissional e Tecnológica, BA, Brasil

fcnunes76@gmail.com

\begin{abstract}
RESUMO
As praias da APA Lagoa Encantada/Rio Almada estão situadas no Litoral Sul da Bahia, apresentam grande beleza cênica e vem sofrendo grande especulação imobiliária, principalmente devido à expansão urbana da cidade de llhéus, crescimento do turismo e, mais recente, ao projeto de instalação do Complexo Porto Sul. O objetivo principal desta pesquisa foi valorar qualitativamente os serviços ecossistêmicos oferecidos pelas praias da APA Lagoa Encantada/Rio Almada e sua zona costeira adjacente, agrupados nas classes de Serviços de Regulação e Suporte, de Provisão e de Informação e Cultura. O estudo mostra que a maioria das praias apresenta bons índices de serviços ecossistêmicos (médio e alto), sendo a exceção a praia intitulada Ponta da Tulha (trecho 2), onde os serviços de suporte e regulação são baixos, o que acabou por repercutir na diminuição da oferta de serviços de provisão, informação e cultura. Observou-se também que quanto maior a concentração dos sistemas técnicos, menor a variedade e a qualidade dos serviços ecossistêmicos disponíveis.
\end{abstract}

Palavras-chave: Gestão Costeira. Economia Ecológica. Resiliência dos Ecossistemas.

\section{QUALITATIVE ASSESSMENT OF ECOSYSTEM SERVICES OFFERED BY THE BEACHES OF THE APA ENCANTADA LAKE / ALMADA RIVER, BAHIA, BRAZIL}

\begin{abstract}
The beaches of the APA Lagoa Encantada/Rio Almada are situated on the South Coast of Bahia, have great scenic beauty and is suffering great real estate speculation, mainly due to urban expansion of the city of llhéus, tourism growth and, more recently, to the setup project Complex Porto Sul. The objective of the research was qualitatively valuing ecosystem services offered by beaches the APA Lagoa Encantada/Rio Almada and its adjacent coastal zone, grouped in the Regulation and Support Services classes, Supply and Information and Culture. The study concluded that most of the beaches has good rates of ecosystem services (medium and high), with the exception of beach Ponta da Tulha (section 2) where the support and regulation services are low, which was reflected in reduced supply of supply, information and culture services. It was also observed that the higher the concentration of technical systems, the lower the variety and quality of ecosystem services.
\end{abstract}

Keywords: Coastal Management. Ecological Economics. Ecosystem Resilience.

\section{INTRODUÇÃO}

Caminhos de Geografia Uberlândia $\quad$ v. 20, n. $72 \quad$ Dez/2019 $\quad$ p. 15-32 Página 15


O intenso debate suscitado pelas primeiras evidências de transgressão dos limites do crescimento material vem respondendo por inovações substanciais nos sistemas de planejamento e gestão governamental. No contexto brasileiro, é a partir da nova Carta Constitucional, em 1988, que as políticas públicas internalizam estes novos desafios de forma mais integrada, acerca do binômio "desenvolvimento e ambiente" (SACHS, 2007).

Base estratégica para exploração dos recursos marinhos, as zonas costeiras oferecem muito além da sua posição privilegiada. Esta abriga um mosaico de ecossistemas de alta relevância ambiental, cuja diversidade é marcada pela transição de ambientes terrestres e marinhos, com interações que the conferem um caráter de fragilidade e que requerem, por isso, atenção especial do poder público (SOUZA FILHO et al., 2014b, BRASIL, 1998).

Neste contexto, as praias podem ser consideradas como recursos naturais que servem de suporte para diversas atividades econômicas com destaque, no momento atual, para o turismo de "sol, areia e mar". Tais recursos dependem sobremaneira dos sistemas ecológicos que conformam o ambiente praial e os elementos estruturais destes ecossistemas, quando combinados, produzem funções e serviços ecossistêmicos. Estes serviços podem ser definidos como uma função do ecossistema, com valor para os seres humanos (DALY e FARLEY, 2004). O conjunto dos diversos serviços ecossistêmicos dá suporte a muitas atividades econômicas que se desenvolvem no ambiente praial, bem como, a uma imensa gama de outros produtos disponibilizados para consumo da sociedade. Contudo, o uso de forma imprudente destes recursos pode reduzir de maneira irreversível a capacidade de carga e resiliência destes ecossistemas. Portanto, a apropriação destes espaços pela sociedade deve ser precedida de cuidados visando fornecer os incentivos certos para proteger a resiliência dos sistemas naturais (SOUZA FILHO et al., 2014a, SANTOS e SILVA, 2012).

Diversos autores têm procurado dimensionar o valor dos serviços prestados pelo ambiente natural, neste sentido, a economia como ciência tem desenvolvido, ao longo dos anos, diversas formas de análise que podem ser divididas em três fases: Economia de Recursos Naturais, Economia Ambiental e Economia Ecológica (MATTOS et al., 2005). Neste período, muitos trabalhos foram publicados com propostas para padronização destes estudos, como, por exemplo, Constanza et al. (1987), Constanza (1989), Constanza (2000), De Groot et al. (2002), Hein et al. (2006), Andrade e Romeiro (2009), Santos e Silva (2012), Clarke et al., 2013, Souza Filho et al. (2014b), Elliff e Kikuchi (2015), dentre outros.

Dentre os esforços acadêmicos citados, Constanza et al. (1987) realizaram um levantamento do valor econômico de dezessete serviços ecossistêmicos para dezesseis biomas, considerando apenas os recursos renováveis e excluindo combustíveis não renováveis e a atmosfera. Este estudo apresentou uma falta de padronização na categorização dos serviços ecossistêmicos e outra importante limitação é a dificuldade em apresentar uma valoração real destes serviços. Em geral a valoração depende do quanto as pessoas estariam dispostas a pagar por um determinado serviço, relativizando, assim, este tipo de avaliação, pois o valor é especifico aos objetivos de escolha (momento), e que as pessoas avaliam de formas diferentes, ou que ainda, uma mesma pessoa pode atribuir dois valores diferentes ao mesmo serviço dependendo do seu estado momentâneo, se tem maior ou menor necessidade do mesmo naquele instante (BOCKSTAEL et al., 2000).

Além disso, estes serviços são geralmente indispensáveis e para muitos, não há quaisquer instituições ou tecnologias que os possam tornar dispensáveis (DALY e FARLEY, 2004; SANTOS e SILVA, 2012).

Nas últimas duas décadas, diversos autores buscaram melhorar as metodologias na tentativa de atingir parâmetros de valoração mais embasados e com aplicabilidade em diferentes áreas. Neste contexto, De Groot et al. (2002) evidenciaram que os dados sobre os serviços ecossistêmicos muitas vezes aparecem em escalas incompatíveis. Ainda segundo estes autores, mesmo que, às vezes, um serviço ecossistêmico seja valorado pelo preço que as pessoas estão dispostas a pagar para ter o serviço, em alguns casos o serviço é tão necessário para a sobrevivência das pessoas, que se torna mais lógico medir o quanto as 
pessoas estariam dispostas a pagar para evitar a perda deste serviço. Merico (1996) destaca que é necessário distinguir-se entre valor de uso e valor intrínseco, entre os diversos tipos de valor econômico relacionado aos recursos naturais. $O$ valor de uso deriva do uso que se faz do ambiente, como a extração de recursos minerais ou a observação de pássaros. Já o valor intrínseco compreende os valores de algum bem, mesmo que potencial, como, por exemplo, uma determinada espécie de planta ocorrente em área especifica ou determinada espécie de inseto.

Partindo do pressuposto que todo serviço ecossistêmico deriva de uma função ecossistêmica, com valor para os seres humanos, De Groot et al (2002), buscaram sistematizar a grande variedade de funções ecossistêmicas através da categorização dos serviços ecossistêmicos ofertados por tais funções, seja individualmente ou em conjunto. Estes autores dividiram as funções ecossistêmicas em quatro diferentes grupos: função de regulação (de gás, clima, água, entre outros), de habitat (locais que proporcionam habitat para espécies da fauna e flora, como refúgios e estuários), de produção (produção de alimento) e de informação (cultural, recreacional, histórica, espiritual, cientifica, etc.), permitindo que, mesmo dentro de ambientes diferentes, os mesmos grupos possam ser comparados entre si. É necessário destacar que tanto as funções de regulação quanto as funções de habitat, proporcionam suporte e manutenção dos componentes naturais, contribuindo para a provisão das demais funções (ANDRADE e ROMEIRO, 2009).

Desta forma, considerando a riqueza ecológica dos ambientes costeiros e a necessidade de um gerenciamento que possa integrar valores econômicos e ambientais, este trabalho teve como objetivo avaliar e valorar qualitativamente os serviços ecossistêmicos oferecidos pelas praias da APA Lagoa Encantada/Rio Almada, Litoral Sul do Estado da Bahia.

Localizada na denominada "Costa do Cacau", este trecho do litoral baiano vem sofrendo grande especulação imobiliária motivada, principalmente, pela expansão urbana da cidade de llhéus, crescimento do turismo e mais recentemente, ao projeto de instalação do "Complexo Porto Sul" (porto, ferrovia e aeroporto). Todavia, esta zona costeira apresenta ecossistemas de alta sensibilidade ambiental e que fornecem importantes serviços ecossistêmicos. Desta forma, a análise e estimativa do valor atual e potencial dos serviços ecossistêmicos oferecidos neste litoral buscam subsidiar ações e programas para o gerenciamento costeiro integrado desta unidade de conservação.

\section{MATERIAL E MÉTODOS}

Para identificação e avaliação dos serviços ecossistêmicos foram realizados caminhamentos, nestes foram utilizados receptor GNSS e câmera fotográfica para registro de ocorrências e posterior análise comparativa com imagens de satélite, bem como, bússola geológica para estimar inclinação da face de praia ao longo do litoral da APA Lagoa Encantada/Rio Almada, onde estão inseridas as praias de Pé de Serra, Sargi, Ponta do Ramo, Luzimares, Ilhéus, Coqueiros, Mamoã, Ponta da Tulha, Verdes Mares, Barramares, Paraíso do Atlântico, Joia do Atlântico, Mar e Sol, Japará, Fazenda de Osmar, São Domingos e São Miguel.

Apesar da maior parte das praias apresentarem uma grande homogeneidade interna nas suas características naturais e de infraestrutura, as praias do Sargi, Mamoã, Ponta da Tulha, Joia do Atlântico e São Domingos apresentaram uma grande variação nas suas características naturais, de ocupação e infraestrutura, estas praias foram segmentadas em trechos com características similares. Visando avaliar os serviços ecossistêmicos durante períodos de uso intenso e também de baixa intensidade, foram realizadas cinco campanhas de campo (três em três meses) ao longo do ano, compreendendo as chamadas "alta" e "baixa" estações turísticas que coincidem com os períodos seco e chuvoso, respectivamente, entre janeiro de 2016 e fevereiro de 2017.

Neste trabalho foram também valorados os ecossistemas associados à praia, assim, limitou-se a zona costeira adjacente a uma faixa de até $200 \mathrm{~m}$, a partir da pós-praia em direção ao continente ou do limite

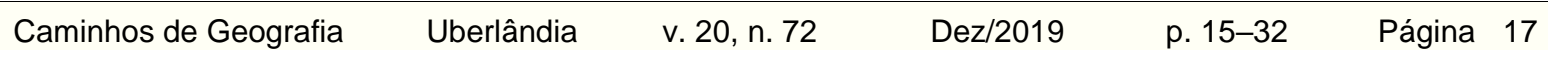


final de ecossistemas com base nos limites genéricos estabelecidos para a orla marítima pelo Projeto Orla (MMA, 2006), permitindo uma análise mais ampla e integrada dos serviços ecossistêmicos oferecidos.

A metodologia aplicada para valoração qualitativa dos serviços ecossistêmicos oferecidos pelas praias da APA Lagoa Encantada/Rio Almada foi elaborada com base na metodologia utilizada apara Avaliação Ecossistêmica do Milênio (MA, 2003) e nas adaptações feitas por Souza Filho et al. (2014a), com o objetivo de fornecer bases científicas para a gestão sustentável dos ecossistemas. Estes autores agruparam os serviços ecossistêmicos em Serviços de Regulação, Serviços de Provisão (ou de abastecimento), Serviços de Suporte e Serviços Culturais. Souza Filho et al. (2014a), optaram por uma avaliação conjunta dos Serviços de Regulação e Suporte, já que os serviços que promovem, por exemplo, a purificação da água, regulação climática e a ciclagem de nutrientes, ajudam a prover habitats e geram serviços de suporte a estes ambientes. Desta forma, na avaliação das praias da APA Lagoa Encantada/Rio Almada e seus ecossistemas associados, os serviços ecossistêmicos foram agrupados em Serviços de Regulação e/ou Suporte, Serviços de Provisão e Serviços de Informação e Cultura.

Dentre os Serviços de Regulação e/ou Suporte encontrados na área de estudo se destacam: a) a retenção natural de sedimentos, que está associado à presença de vegetação na pós-praia ou no cordão duna, pois, considera-se que o sistema de raízes atua como fixador natural de sedimentos; b) a recarga de aquíferos, associado à presença de unidades geológicas permeáveis, como os terraços marinhos holocênicos e pleistocênicos, na zona costeira adjacente à praia; c) o controle e estocagem de água, associado à presença de terras úmidas e/ou manguezais do Rio Almada, lagoas e foz de pequenos riachos, uma vez que estes ecossistemas armazenam água e regulam o nível do lençol freático, além de equilibrar o balanço térmico local; d) a assimilação e reciclagem de poluentes, que também está associada à presença das terras úmidas e/ou manguezais, pois o solo argiloso presente nestes ecossistemas funciona muitas vezes assimilando e reciclando poluentes, obviamente respeitando seu limite de resiliência; e) a dissipação da energia das ondas, associada à presença de zona de surfe, considerando que, quanto maior o número de linhas de arrebentação e mais extensa a zona de surfe, maior a dissipação da energia das ondas antes de atingir a face da praia; f) a proteção natural na zona de póspraia, associada à presença de cordão-duna, promovendo uma proteção natural à zona costeira adjacente, principalmente durante eventos extremos, onde grandes ondas podem atingir a costa; g) o refugio e/ou berçário marinho, possibilitando principalmente a manutenção da produtividade primaria, associados à presença de estuários, recifes de corais e áreas de desova de tartaruga marinha e; h) o refugio e/ou berçário terrestre ou transicional, que possibilita também a manutenção da produtividade primária e está associado à presença de manguezais, restinga ou Mata Atlântica na zona costeira adjacente.

Quanto aos Serviços de Provisão foram considerados: a) a produção natural de alimentos, associado à presença de atividades que provem recursos para alimentação como pesca, mariscagem ou produção vegetal, excluindo os cultivos humanos; b) a produção de alimentos em áreas cultivadas, por contado fornecimento de recursos para alimentação através dos cultivos ou criação de animais; c) os recursos hídricos, ligados à presença de rios, lagos, aquíferos etc., que sirvam para o uso humano; d) os recursos ornamentais associados à presença de recursos que possam ser usados para fins ornamentais e de artesanato (ostras, madeira morta, etc.) e; e) recursos genéticos, associados à presença de ecossistemas heterogêneos, com alta biodiversidade, que possibilitem um alto fluxo genético, considerando menor potencial em pastos ou monoculturas, médio em restingas ou sistemas agroflorestais e maior em florestas, bancos de corais, estuários e manguezais.

No caso dos Serviços de Informação e Cultura foram considerados: a) o ecoturismo, com a presença de locais atrativos para ecoturismo (trilhas, mergulhos, etc.); b) o turismo cultural e/ou histórico devido à presença de construções ou áreas com valor histórico e/ou cultural, como, por exemplo, áreas de "cabruca" (sistema agroflorestal de produção do cacau) e locais para venda de chocolate artesanal com amêndoas do "cacau cabruca"; c) a recreação e lazer, neste caso, associado à qualidade recreacional das 
praias estabelecida em Souza Filho et al. (2014b. p.32), utilizando indicadores geoambientais e de infraestrutura e; d) a atratividade cênica ligada à presença de atrativos naturais que estimulam a visitação local, além da própria faixa arenosa e marinha, como, por exemplo, o promontório de Serra Grande.

As características e critérios adotados nesta valoração são apresentados nos Quadros 1, 2 e 3, sendo para cada serviço (ou ausência deste) atribuída a qualificação de baixo (valor 1), médio (valor 2) ou alto (valor 3). Algumas características, como, por exemplo, a presença de terras úmidas e manguezais são valoradas mais de uma vez, visto que oferecem mais de um serviço ecossistêmico.

Quadro 1 - Parâmetros para valoração dos serviços ecossistêmicos de regulação e suporte.

\begin{tabular}{|c|c|c|c|}
\hline $\begin{array}{c}\text { Serviço de Regulação } \\
\text { e/ou Suporte }\end{array}$ & Baixo (1) & Médio (2) & Alto (3) \\
\hline $\begin{array}{l}\text { Retenção Natural de } \\
\text { Sedimentos }\end{array}$ & $\begin{array}{l}\text { Ausência de vegetação } \\
\text { na pós-praia ou no } \\
\text { cordão-duna }\end{array}$ & $\begin{array}{l}\text { Ocorrência de vegetação } \\
\text { na pós-praia ou no } \\
\text { cordão-duna em menos } \\
\text { de } 50 \% \text { do litoral }\end{array}$ & $\begin{array}{l}\text { Ocorrência de vegetação } \\
\text { na pós-praia ou no cordão- } \\
\text { duna em mais de } 50 \% \text { do } \\
\text { litoral }\end{array}$ \\
\hline Recarga de Aquíferos & $\begin{array}{l}\text { Ausência de terraços } \\
\text { arenosos ou terraços } \\
\text { com superfície } \\
\text { impermeabilizada }\end{array}$ & $\begin{array}{l}\text { Ocorrência de terraços } \\
\text { arenosos em menos de } \\
50 \% \text { do litoral }\end{array}$ & $\begin{array}{l}\text { Ocorrência de terraços } \\
\text { arenosos em mais de } 50 \% \\
\text { do litoral }\end{array}$ \\
\hline $\begin{array}{l}\text { Controle e Estocagem } \\
\text { de Água }\end{array}$ & $\begin{array}{l}\text { Ausência de terras } \\
\text { úmidas ou manguezais }\end{array}$ & $\begin{array}{l}\text { Ocorrência de terras } \\
\text { úmidas ou manguezais } \\
\text { em menos de } 50 \% \text { do } \\
\text { litoral }\end{array}$ & $\begin{array}{l}\text { Ocorrência de terras } \\
\text { úmidas ou manguezais em } \\
\text { mais de } 50 \% \text { do litoral }\end{array}$ \\
\hline $\begin{array}{l}\text { Assimilação } \\
\text { Reciclagem } \\
\text { Poluentes }\end{array}$ & $\begin{array}{l}\text { Ausência de terras } \\
\text { úmidas ou manguezais }\end{array}$ & $\begin{array}{l}\text { Ocorrência de terras } \\
\text { úmidas ou manguezais } \\
\text { em menos de } 50 \% \text { do } \\
\text { litoral }\end{array}$ & $\begin{array}{l}\text { Ocorrência de terras } \\
\text { úmidas ou manguezais em } \\
\text { mais de } 50 \% \text { do litoral }\end{array}$ \\
\hline $\begin{array}{l}\text { Dissipação da Energia } \\
\text { das Ondas }\end{array}$ & $\begin{array}{l}\text { Ausência de zona de } \\
\text { surfe }\end{array}$ & $\begin{array}{l}\text { Zona de surfe com até } 3 \\
\text { linhas de arrebentação }\end{array}$ & $\begin{array}{l}\text { Zona de surfe com mais de } \\
3 \text { linhas de arrebentação }\end{array}$ \\
\hline $\begin{array}{l}\text { Proteção Natural na } \\
\text { Zona de Ante-praia }\end{array}$ & $\begin{array}{l}\text { Ausência de recifes de } \\
\text { corais e/ou bancos de } \\
\text { arenito }\end{array}$ & $\begin{array}{l}\text { Ocorrência de recifes de } \\
\text { corais e/ou bancos de } \\
\text { arenito em menos de } \\
50 \% \text { do litoral }\end{array}$ & $\begin{array}{l}\text { Ocorrência de recifes de } \\
\text { corais e/ou bancos de } \\
\text { arenito em mais de } 50 \% \text { do } \\
\text { litoral }\end{array}$ \\
\hline $\begin{array}{l}\text { Proteção Natural na } \\
\text { Zona de Pós-praia }\end{array}$ & Ausência de cordão-duna & $\begin{array}{l}\text { Ocorrência de cordão- } \\
\text { duna em menos de } 50 \% \\
\text { do litoral }\end{array}$ & $\begin{array}{l}\text { Ocorrência de cordão-duna } \\
\text { em mais de } 50 \% \text { do litoral }\end{array}$ \\
\hline $\begin{array}{l}\text { Refúgio e/ou Berçário } \\
\text { Marinho }\end{array}$ & $\begin{array}{l}\text { Ausência de estuários, } \\
\text { recifes de coral ou áreas } \\
\text { de desova de tartaruga } \\
\text { marinha }\end{array}$ & $\begin{array}{l}\text { Ocorrência de pelo } \\
\text { menos } \\
\text { refúgio/berçário } \\
\text { (estuários, recifes de } \\
\text { coral ou áreas de } \\
\text { desova de tartaruga } \\
\text { marinha) }\end{array}$ & $\begin{array}{l}\text { Ocorrência de mais um } \\
\text { refúgio/berçário (estuários, } \\
\text { recifes de coral ou áreas } \\
\text { de desova de tartaruga } \\
\text { marinha) }\end{array}$ \\
\hline $\begin{array}{lr}\text { Refúgio e/ou } & \text { Berçário } \\
\text { Terrestre } & \text { ou } \\
\text { Transicional } & \end{array}$ & $\begin{array}{l}\text { Ausência de } \\
\text { manguezais, restingas ou } \\
\text { Mata Atlântica }\end{array}$ & $\begin{array}{l}\text { Ocorrência de pelo } \\
\text { menos } \\
\text { refúgio/berçário } \\
\text { (manguezal, restinga, } \\
\text { Mata Atlântica) }\end{array}$ & $\begin{array}{l}\text { Ocorrência de mais de um } \\
\text { refúgio/berçário } \\
\text { (manguezal, restinga, Mata } \\
\text { Atlântica) }\end{array}$ \\
\hline
\end{tabular}

Fonte - Adaptado de Santos e Silva (2012). 
Quadro 2 - Parâmetros para valoração dos serviços ecossistêmicos de provisão.

\begin{tabular}{|c|c|c|c|}
\hline Serviço de Provisão & Baixo (1) & Médio (2) & Alto (3) \\
\hline $\begin{array}{l}\text { Produção Natural de } \\
\text { Alimentos }\end{array}$ & $\begin{array}{l}\text { Ausência de atividades } \\
\text { como pesca, mariscagem } \\
\text { ou produção vegetal }\end{array}$ & $\begin{array}{l}\text { Ocorrência de pelo } \\
\text { menos uma atividade } \\
\text { (ex. pesca, mariscagem } \\
\text { ou produção vegetal) }\end{array}$ & $\begin{array}{l}\text { Ocorrência de mais de uma } \\
\text { atividade (ex. pesca, } \\
\text { mariscagem ou produção } \\
\text { vegetal) }\end{array}$ \\
\hline $\begin{array}{l}\text { 1. Produção de } \\
\text { Alimentos em Áreas } \\
\text { Cultivadas }\end{array}$ & $\begin{array}{l}\text { Ausência de atividades } \\
\text { como plantações, criação } \\
\text { de animais, piscicultura, } \\
\text { etc. }\end{array}$ & $\begin{array}{l}\text { Ocorrência de pelo } \\
\text { menos uma atividade } \\
\text { (ex. plantações, criação } \\
\text { de animais, piscicultura) }\end{array}$ & $\begin{array}{l}\text { Ocorrência de mais de uma } \\
\text { atividade (ex. plantações, } \\
\text { criação de animais, } \\
\text { piscicultura) }\end{array}$ \\
\hline Recursos Hídricos & $\begin{array}{l}\text { Ausência de corpos } \\
\text { d'água superficiais ou } \\
\text { aquíferos }\end{array}$ & $\begin{array}{l}\text { Ocorrência de pelo } \\
\text { menos uma fonte de } \\
\text { recursos hídricos (ex. } \\
\text { rios, lagoas, aquíferos) }\end{array}$ & $\begin{array}{l}\text { Ocorrência de mais de uma } \\
\text { fonte de recursos hídricos } \\
\text { (ex. rios, lagoas, aquíferos) }\end{array}$ \\
\hline Recursos Ornamentais & $\begin{array}{l}\text { Ausência de recursos } \\
\text { ornamentais (ex. madeira } \\
\text { morta, ostra, vegetais, } \\
\text { peixes, rochas, minerais) }\end{array}$ & $\begin{array}{l}\text { Ocorrência de pelo } \\
\text { menos um recurso } \\
\text { ornamental (ex. madeira } \\
\text { morta, ostra, vegetais, } \\
\text { peixes, rochas, minerais) }\end{array}$ & $\begin{array}{l}\text { Ocorrência de mais de um } \\
\text { recurso ornamental (ex. } \\
\text { madeira morta, ostra, } \\
\text { vegetais, peixes, rochas, } \\
\text { minerais) }\end{array}$ \\
\hline Recursos Genéticos & $\begin{array}{l}\text { Ocorrência de áreas } \\
\text { antropizadas, pastos ou } \\
\text { monoculturas }\end{array}$ & $\begin{array}{l}\text { Ocorrência de restingas } \\
\text { ou } \\
\text { agroflorestais }\end{array}$ & $\begin{array}{l}\text { Ocorrência de florestas, } \\
\text { corais, estuários ou } \\
\text { manguezais }\end{array}$ \\
\hline
\end{tabular}

Fonte - Adaptado de Santos e Silva (2012).

Quadro 3 - Parâmetros para valoração dos serviços ecossistêmicos de informação e cultura.

\begin{tabular}{|c|c|c|c|}
\hline $\begin{array}{c}\text { Serviço de } \\
\text { Informação, Cultura e } \\
\text { Lazer }\end{array}$ & Baixo (1) & Médio (2) & Alto (3) \\
\hline Ecoturismo & $\begin{array}{l}\text { Ausência de locais com } \\
\text { atratividade para } \\
\text { ecoturismo, como trilhas } \\
\text { e mergulhos }\end{array}$ & 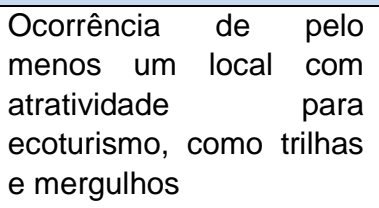 & $\begin{array}{l}\text { Ocorrência de mais de um } \\
\text { local com atratividade para } \\
\text { ecoturismo, como trilhas e } \\
\text { mergulhos }\end{array}$ \\
\hline $\begin{array}{l}\text { Turismo } \\
\text { Histórico/Cultural }\end{array}$ & $\begin{array}{l}\text { Ausência de construções } \\
\text { ou áreas de reconhecido } \\
\text { valor histórico }\end{array}$ & $\begin{array}{l}\text { Ocorrência de pelos } \\
\text { menos uma construção } \\
\text { ou área de reconhecido } \\
\text { valor histórico }\end{array}$ & $\begin{array}{l}\text { Ocorrência de mais de uma } \\
\text { construção ou área de } \\
\text { reconhecido valor histórico }\end{array}$ \\
\hline Recreação e Lazer & $\begin{array}{ll}\text { Baixa } & \text { qualidade } \\
\text { recreacional } & \end{array}$ & $\begin{array}{l}\text { Qualidade recreacional } \\
\text { média }\end{array}$ & Alta qualidade recreacional \\
\hline Atratividade Cênica & $\begin{array}{l}\text { Ausência de atrativos } \\
\text { naturais (ex. falésias) }\end{array}$ & $\begin{array}{l}\text { Ocorrência de pelo } \\
\text { menos um atrativo } \\
\text { natural (ex. falésias) }\end{array}$ & $\begin{array}{l}\text { Ocorrência de mais de um } \\
\text { atrativo natural (ex. } \\
\text { falésias) }\end{array}$ \\
\hline
\end{tabular}

Fonte - Adaptado de Santos e Silva (2012).

\section{Área de Estudo}

As praias da APA Lagoa Encantada/Rio Almada estão situadas no litoral sul a leste baiano (Figura 1), inseridas na Macrorregião Pluviométrica VI do Estado da Bahia (INGÁ/CEMBA, 2009), onde as chuvas são bem distribuídas ao longo do ano.

Caminhos de Geografia Uberlândia $\quad$ v. 20, n. $72 \quad$ Dez/2019 $\quad$ p. 15-32 Página 20


Figura 1 - Localização da área de estudos ao longo das Praias da APA Lagoa Encantada/Rio Almada, Municípios de llhéus e Uruçuca, Estado da Bahia.

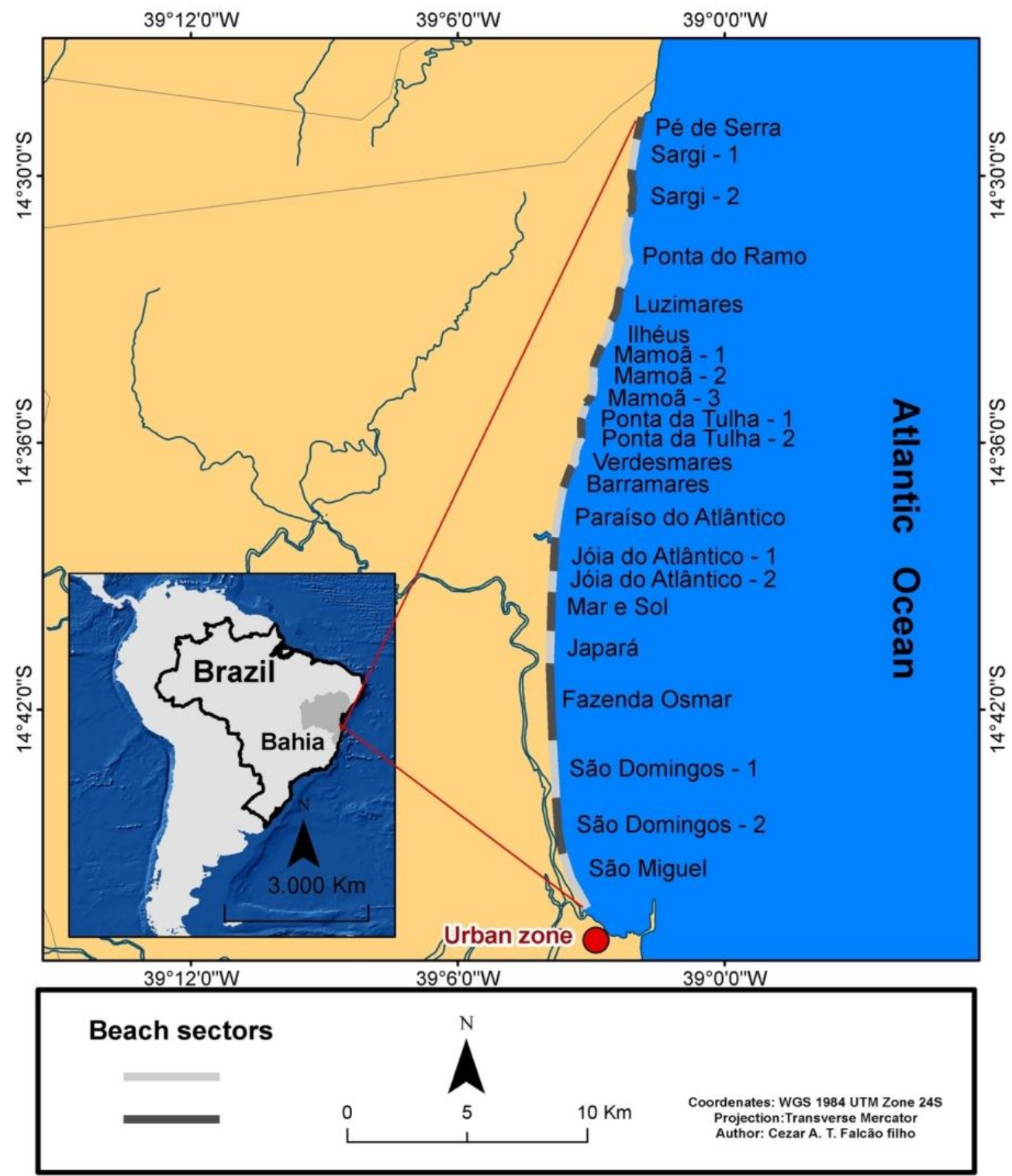

Os sistemas meteorológicos mais importantes que atuam na área são a Zona de Convergência Intertropical (ZCIT), a Zona de Convergência do Atlântico Sul (ZCAS), os Sistemas Frontais (SF), os Vórtices Ciclônicos de Ar Superior (VCAS), os Distúrbios de Leste (DL) e os sistemas de Brisas. O clima é Af na classificação de Koppen e B3rA'a' (úmido) na classificação de Thornthwaite e Mather, possui alto índice de precipitação, normalmente superando $2.000 \mathrm{~mm}$ anuais e temperaturas médias superiores a $24^{\circ} \mathrm{C}$ (MATOS, 2006; INMET, 2016).

Quanto a geologia, essa região costeira é delimitada na sua parte mais interna basicamente por sedimentos quaternários, em sua maioria, terraços marinhos holocênicos e pleistocênicos, sedimentos marinhos de praia, depósitos de mangue e sedimentos flúvio-lacustres. As acumulações fluviomarinhas são mapeadas na foz do rio Almada e de pequenos riachos que drenam a parte norte da APA, formando áreas de mangues, pântanos e antigas lagunas, seus depósitos correlativos são de composição sílticoargilosa ricos em matéria orgânica (Figura 2). Dentre os sedimentos marinhos de praia são encontrados sedimentos arenosos amarelo-esbranquiçados, compostos essencialmente por areias medias a finas ricas em quartzo e, secundariamente, em fragmentos de conchas e minerais opacos (Figura 3) (CPRM, 1991; BAHIA, 2011). 
Figura 2 - Pântanos e Mangues associados a foz de pequeno riacho na Praia do Japará, llhéus.

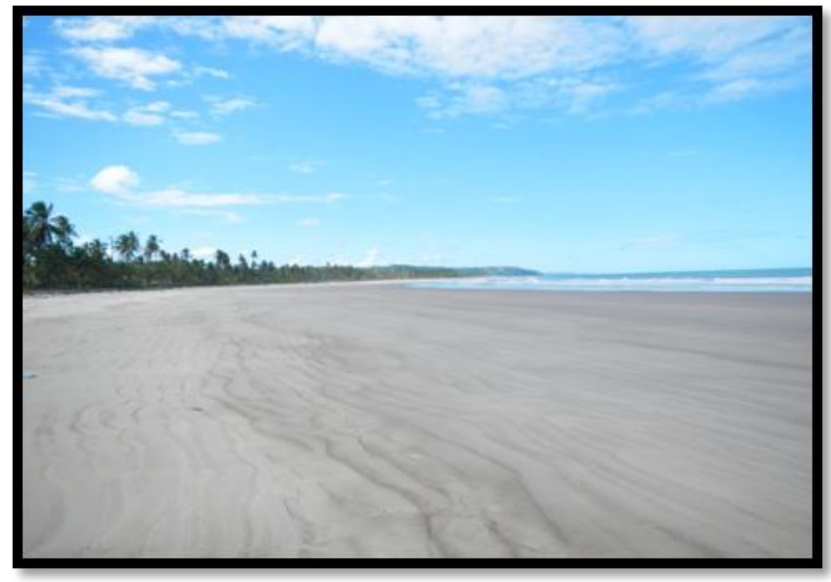

Figura 3 - Sedimentos Marinhos de Praia na Ponta da Tulha, Ilhéus.

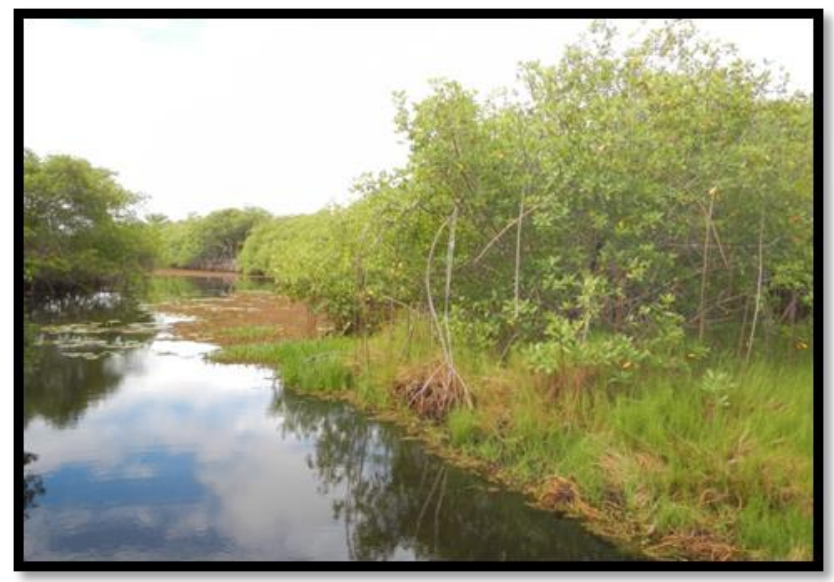

Unindo riqueza ecológica e facilidade de acesso aos seus aproximadamente $34 \mathrm{~km}$ de praias, a zona costeira da APA Lagoa Encantada/Rio Almada representa uma importante área para o crescimento e desenvolvimento turístico do Estado da Bahia (Figura 4). Contudo, na atualidade, cresce a preocupação com os possíveis impactos que a instalação do "Complexo Porto Sul" acarretará em sua dinâmica socioambiental.

Figura 4 - Vista das Praias do Pé de Serra e Sargi, Mirante de Serra Grande, Uruçuca.

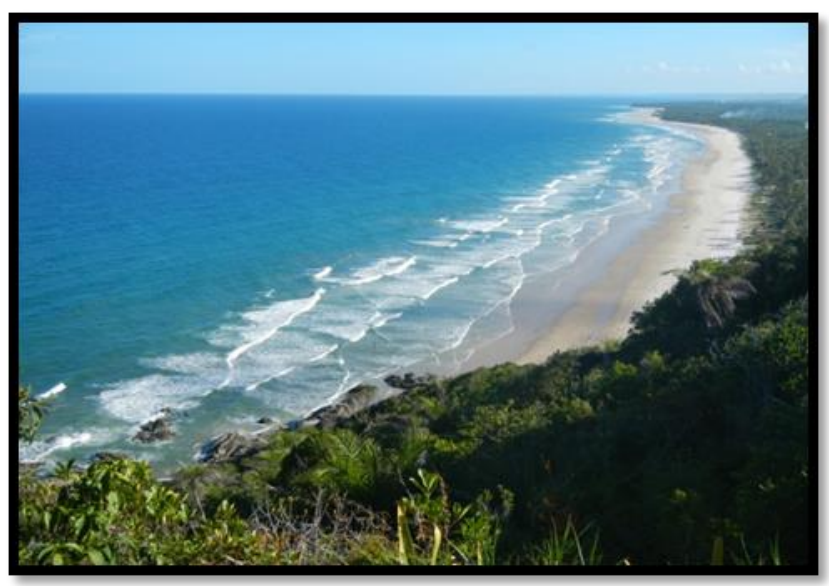




\section{RESULTADOS E DISCUSSÃO}

Algumas das praias da APA Lagoa Encantada/Rio Almada (Sargi, Mamoã, Ponta da Tulha, Joia do Atlântico e São Domingos), como dito anteriormente, foram segmentadas em trechos com características similares, pois apresentaram uma grande variação nas suas características naturais, de ocupação e infraestrutura.

A praia do Pé de Serra: no extremo norte da linha de costa estudada, é caracterizada pela ocorrência de vegetação em mais de $50 \%$ na pós-praia; terraços arenosos em mais de $50 \%$ de sua extensão litorânea; ocorrência de terras úmidas em menos de $50 \%$ do seu litoral; zona de surfe com até três linhas de arrebentação; ausência de proteção natural na zona de ante-praia; ocorrência de cordão-duna em mais de $50 \%$ do litoral; presença de estuário e manguezal que servem como refúgio e/ou berçário, os quais perderam a ligação direta com o mar devido a bancos de areia, apenas ultrapassados em marés mais altas e em tempestades; atividades de pesca artesanal; ocorrência de recurso ornamental (madeira morta e vegetais); remanescente de floresta ombrófila (Mata Atlântica); ocorrência de atividades ecoturísticas e turismo de aventura (trilha ecológica, voo de parapente e tirolesa); ausência de construções e áreas de reconhecido valor histórico; qualidade recreacional média, segundo indicadores geoambientais e de infraestruturas; e ocorrência de importante atratividade cênica natural, o promontório rochoso que da base a dois belos mirantes (Figura 2).

Figura 2 - Vista 3D da Praia do Pé de Serra, Mirantes 1 e 2, Costão Rochoso e Vila de Serra Grande, Uruçuca/BA.

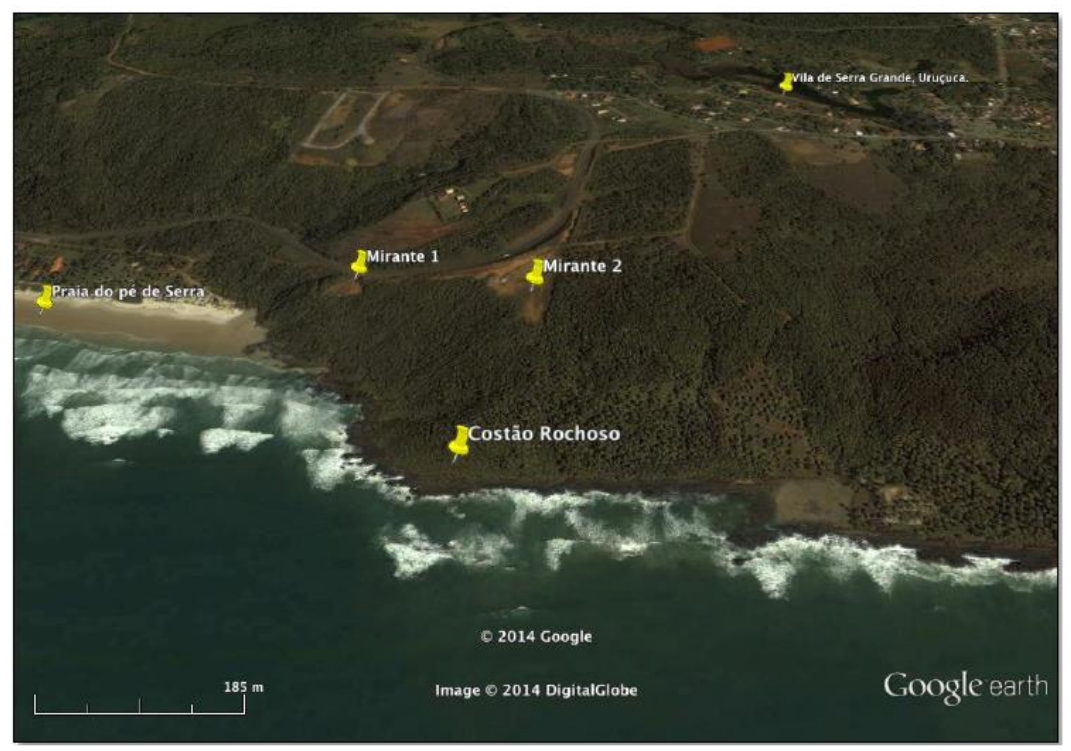

Fonte - Google Earth (acesso em 05. jun. 2014).

A praia de Sargi - trecho 1: é caracterizada pela ocorrência de vegetação em mais de $50 \%$ na pós-praia; terraços arenosos em toda sua extensão; terras úmidas em menos de $50 \%$ da praia; dissipação média das energias das ondas,com até três linhas de arrebentação; ausência de recifes de corais e/ou bancos de arenitos agindo como proteção na ante-praia; ocorrência de cordão-duna em mais de $50 \%$ do litoral;presença de um refúgio e/ou berçário para tartarugas marinhas, dentre outros; atividade de pesca artesanal; ocorrência de pelo menos uma atividade de produção de alimentos (coco da baia); ocorrência de mais de uma fonte de recursos hídricos, a exemplo do pequeno riacho que desemboca nessa praia; presença de recurso ornamental (vegetais); ocorrência de restinga arbustiva;ausência de construções e áreas de reconhecido de valor histórico; qualidade recreacional média e ausência de atrativos naturais, fora a própria faixa arenosa e marinha.

Praia de Sargi - trecho 2: possui serviços de regulação e suporte similares aos do trecho 1, contudo a ocorrência de vegetação na pós-praia é menor que 50\% e apresenta mais de um refúgio/berçário terrestre e marinho (estuário e área de desova para tartarugas marinhas). Os serviços de provisão destoam pela

Caminhos de Geografia Uberlândia $\quad$ v. 20, n. $72 \quad$ Dez/2019 p. 15-32 Página 23


elevada produção natural de alimentos e recursos genéticos, devido a forte presença de mangues e área úmidas na Foz do Rio Sargi (divisa dos municípios Ilhéus e Uruçuca), enquanto que os serviços relacionados a informação e cultura destoam apenas pela elevada atratividade cênica do estuário e seu potencial para o ecoturismo (Figura 3).

Figura 3. Vista da Foz do Rio Sargi na divisa llhéus/Uruçuca a partir da Ponta do Ramo, llhéus.

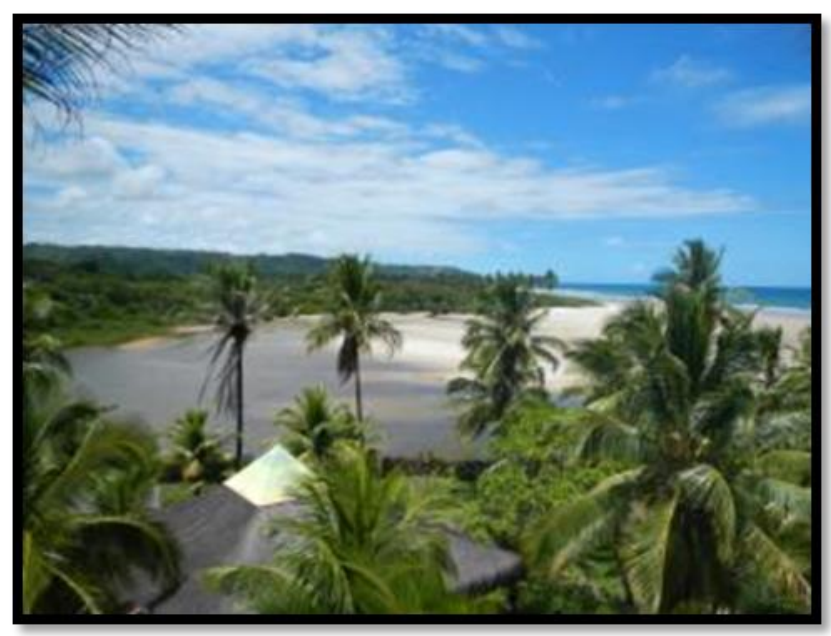

A praia de Ponta do Ramo: é caracterizada pela ocorrência de vegetação em mais de $50 \%$ na pós-praia; terraços arenosos em mais de $50 \%$ de sua extensão; ocorrência de terras úmidas em menos de $50 \%$ do seu litoral; zona de surfe com até três linhas de arrebentação; ausência de recifes de corais e/ou bancos de arenitos agindo como proteção na ante-praia; ocorrência de cordão-duna em menos de 50\% do litoral; presença de mais de uma área servindo como refúgio e/ou berçário marinho e terrestre; ocorrência de mais de uma atividade destinada à provisão de alimentos (pesca e mariscagem); extensas plantações de coco da baía para produção de alimentos; ocorrência de mais de uma fonte de recursos hídricos (Rio Sargi, lagoas e aquíferos); ocorrência de recursos ornamentais (madeira morta, vegetais); ocorrência de estuário e manguezal; alta atratividade cênica natural para ecoturismo; ausência de construções e áreas de reconhecido de valor histórico; qualidade recreacional média e presença de mais de um atrativo natural, como o belo estuário, manguezal e lagoas.

A praia de Luzimares: é caracterizada pela ocorrência de vegetação em mais de $50 \%$ na pós-praia; ocorrência de terraços arenosos em mais de $50 \%$ de sua extensão; ocorrência de terras úmidas em menos de $50 \%$ do seu litoral; dissipação média das energias das ondas; ausência de recifes de corais e/ou bancos de arenitos agindo como proteção na ante-praia; ocorrência de cordão-duna em menos de $50 \%$ do litoral; presença de apenas uma área servindo como refúgio e/ou berçário marinho (desova de tartarugas marinhas); ocorrência apenas de uma atividade destinada à provisão de alimentos; presença de pelo menos uma atividade de produção de alimentos em áreas cultivadas; ocorrência de mais de uma fonte de recursos hídricos (riachos e aquíferos); ausência recursos ornamentais; presença de recursos genéticos em área de restinga; sem atratividade cênica para atividades ecoturísticas; ausência de construções e áreas de reconhecido de valor histórico; qualidade recreacional média e; ausência de atrativos naturais, como falésias e matas.

A praia de Coqueiros: é caracterizada pela ocorrência de vegetação em mais de $50 \%$ na pós-praia; ocorrência de terraços arenosos em mais de $50 \%$ de sua extensão; ocorrência de terras úmidas em menos de $50 \%$ do seu litoral; dissipação média das energias das ondas, com até três linhas de arrebentação; sem proteção natural na ante-praia (ausência de recifes de corais e/ou bancos de arenitos); ocorrência de cordão-duna em menos de $50 \%$ do litoral; presença de apenas uma área servindo como refúgio e/ou berçário marinho; presença de um refúgio e/ou berçário terrestre; ocorrência apenas de uma atividade destinada à provisão de alimentos (pesca); presença de pelo menos uma atividade de produção de alimentos em áreas cultivadas (coco da baía); ocorrência de mais de uma fonte de recursos hídricos; ausência recursos ornamentais; presença de recursos genéticos em área de restinga; sem atratividade cênica para atividades ecoturísticas; ausência de construções e áreas de reconhecido de valor histórico; qualidade recreacional média e; ausência de atrativos naturais, além da sua própria faixa arenosa e marinha.

\begin{tabular}{lllll}
\hline Caminhos de Geografia $\quad$ Uberlândia & v. 20, n. $72 \quad$ Dez/2019 & p. 15-32 & Página 24
\end{tabular}


A praia de Mamoã - trecho 1: é caracterizada pela ocorrência de vegetação em mais de $50 \%$ na póspraia; ocorrência de terraços arenosos em mais de $50 \%$ de sua extensão; ocorrência de terras úmidas em menos de $50 \%$ do seu litoral; zona de surfe com até três linhas de arrebentação; ausência de recifes de corais e/ou bancos de arenitos; ocorrência de cordão-duna em mais de $50 \%$ de seu litoral; presença de apenas uma área servindo como refúgio e/ou berçário marinho; presença de um refúgio e/ou berçário terrestre; ocorrência pelo menos de uma atividade destinada à provisão de alimentos; ausência de atividades de produção de alimentos em áreas cultivadas; ocorrência de uma fonte de recursos hídricos; ausência recursos ornamentais; presença de recursos genéticos em área de restinga (biodiversidade alta); sem atratividade cênica para atividades ecoturísticas; ausência de construções e áreas de reconhecido de valor histórico; qualidade recreacional média e; ausência de atrativos cênicos naturais, além da sua própria faixa de praia e mar.

A praia de Mamoã - trecho 2: difere do Mamoã - trecho 1, quanto aos serviços de regulação e suporte por possuir menor retenção natural de sedimentos na pós-praia, isto porque apresenta menos de $50 \%$ de seu litoral recoberto por vegetação, além disso, a zona de pós-praia é totalmente desprotegida por causa da ausência de cordão duna, e não apresenta áreas de suporte para reprodução e refúgio marinho. Quanto aos serviços de provisão, o trecho 2 difere do trecho 1 pela ocorrência de pelo menos uma atividade em áreas cultivadas destinada a produção de alimentos e pela presença de pelo menos um recurso ornamental. Os serviços de informação e cultura são similares ao do trecho 1.

A praia de Mamoã - trecho 3: é bem diferente das praias do Mamoã - trechos 1 e 2, apresentando elevado índice de serviços ecossistêmicos. Esse trecho é caracterizado pela ocorrência de vegetação em mais de 50\% na pós-praia; ocorrência de terraços arenosos em mais de 50\% de sua extensão; ocorrência de terras úmidas em mais de $50 \%$ do seu litoral; zona de surfe com até três linhas de arrebentação; ausência de recifes de corais e/ou bancos de arenitos; ocorrência de cordão-duna em mais de $50 \%$ de seu litoral; presença de pelo menos um refúgio e/ou berçário marinho; presença de mais de uma área servindo como refúgio e/ou berçário terrestre; ocorrência de mais de uma atividade destinada à provisão de alimentos; presença de pelo menos uma atividades destinada a produção de alimentos em áreas cultivadas; ocorrência de mais de uma fonte de recursos hídricos;presença de pelo menos um recursos ornamental; presença de estuário com importante fluxo de biodiversidade; ausência de construções e áreas de reconhecido de valor histórico; qualidade recreacional média e; presença de pelo menos um atrativo cênico natural (belo estuário).

A praia de Ponta da Tulha - trecho 1: é caracterizada pela ocorrência de vegetação em mais de $50 \%$ na pós-praia; ocorrência de terraços arenosos em mais de $50 \%$ de sua extensão; ocorrência de terras úmidas em menos de $50 \%$ do seu litoral; zona de surfe com até três linhas de arrebentação; ausência de recifes de corais e/ou bancos de arenitos, agindo como quebra-mar natural; ocorrência de cordão-duna em mais de $50 \%$ de seu litoral; presença de pelo menos uma área servindo como refúgio e/ou berçário marinho; presença de mais de uma área servindo como refúgio e/ou berçário terrestre; ocorrência de mais de uma atividade destinada à provisão de alimentos (pesca e mariscagem); presença de pelo menos uma atividade destinada a produção de alimentos em áreas cultivadas (coco da baía); ocorrência de pelo menos uma fonte de recursos hídricos; presença de recursos ornamentais (madeira morta e vegetais); presença de recursos genéticos em estuário (biodiversidade alta); atratividade cênica para atividades ecoturísticas; ausência de construções e áreas de reconhecido de valor histórico; qualidade recreacional média e; presença de pelo menos um atrativo cênico natural (estuário).

A praia de Ponta da Tulha - trecho 2: é bem diferente da Ponta da Tulha - trecho 1, apresentando baixo índice de serviços ecossistêmicos. Essa praia é caracterizada pela ocorrência de vegetação em menos de $50 \%$ na pós-praia; ocorrência de terraços arenosos em mais de 50\% de sua extensão; ausência de terras úmidas em seu litoral; zona de surfe com até três linhas de arrebentação; ausência de recifes de corais e/ou bancos de arenitos, atuando como proteção na ante-praia; ausência de cordão-duna; ausência de áreas servindo como refúgio e/ou berçário marinho ou terrestre; ocorrência de pelo menos uma atividade destinada à provisão de alimentos (pesca); presença de pelo menos uma atividade destinada à produção de alimentos em áreas cultivadas (coco da baía); ausência de fonte de recursos hídricos; ausência de recursos ornamentais; grande ocorrência de áreas antropizadas (acima de 70\%); sem atratividade cênica para atividades ecoturísticas; ausência de construções e áreas de reconhecido de valor histórico; qualidade recreacional média e; ausência de atrativos cênicos naturais.

A praia de Verdesmares: é caracterizada pela ocorrência de vegetação em mais de $50 \%$ na pós-praia; ocorrência de terraços arenosos em mais de $50 \%$ de sua extensão; presença de terras úmidas em menos de $10 \%$ do seu litoral; zona de surfe com até três linhas de arrebentação; ausência de recifes de corais e/ou bancos de arenitos, atuando como proteção na ante-praia; ocorrência de cordão-duna em menos de $50 \%$ de seu litoral; presença de refúgio e/ou berçário marinho (recifes de corais); presença de pelo menos

Caminhos de Geografia Uberlândia $\quad$ v. 20, n. $72 \quad$ Dez/2019 $\quad$ p. 15-32 Página 25


uma área que pode servir como refúgio e/ou berçário terrestre (restinga); ocorrência de pelo menos uma atividade destinada à provisão de alimentos (pesca); presença de pelo menos uma atividade destinada à produção de alimentos em áreas cultivadas (coco da baía); presença de pelo menos uma fonte de recursos hídricos; presença de recursos ornamentais; presença de restinga; sem atratividade cênica para atividades ecoturísticas; ausência de construções e áreas de reconhecido de valor histórico; qualidade recreacional média e; ausência de atrativos cênicos naturais, além da sua própria faixa de praia e mar.

A praia de Barramares: possui as mesmas características dos serviços de regulação, provisão, de informação e cultura identificadas na praia Verdesmares sendo, sob o aspecto ecológico, uma continuação do trecho anterior.

A praia Paraíso do Atlântico: é caracterizada pela ocorrência de vegetação em mais de $50 \%$ na póspraia; ocorrência de terraços arenosos em mais de $50 \%$ de sua extensão; presença de terras úmidas em pelo menos de $50 \%$ do seu litoral; dissipação média da energia das ondas, com três linhas de arrebentação; ausência de proteção natural na ante-praia (recifes ou terraços de abrasão); ocorrência de cordão-duna em mais de $50 \%$ de seu litoral; presença de pelo menos uma área servindo como refúgio e/ou berçário marinho; presença de pelo menos um refúgio e/ou berçário terrestre; ocorrência de atividade destinada à provisão de alimentos (pesca); presença de pelo menos uma atividade destinada à produção de alimentos em áreas cultivadas (coco da baía); presença de mais de uma fonte de recursos hídricos; presença de recursos ornamentais (madeira morta e vegetais); ocorrência de restinga e mangue; atratividade cênica para atividades ecoturísticas; ausência de construções e áreas de reconhecido de valor histórico; qualidade recreacional média e; ocorrência de pelo menos um atrativo cênico natural (estuário e manguezal).

A praia Jóia do Atlântico - trecho 1: é caracterizada pela ocorrência de vegetação em mais de $50 \%$ na pós-praia; ocorrência de terraços arenosos em mais de $50 \%$ de sua extensão; presença de terras úmidas em pelo menos de $50 \%$ do seu litoral; dissipação média da energia das ondas, com até três linhas de arrebentação; ausência de recifes de corais e/ou bancos de arenitos, atuando como proteção na antepraia; ocorrência de cordão-duna em menos de $50 \%$ de seu litoral; presença de refúgio e/ou berçário marinho e terrestre (mangue, restinga, áreas úmidas); ocorrência de pelo menos uma atividade destinada à provisão de alimentos (pesca); presença de pelo menos uma atividade destinada à produção de alimentos em áreas cultivadas; presença de mais de uma fonte de recursos hídricos (riachos e aquíferos); presença de fonte de recursos ornamentais (madeira morta e vegetais); ocorrência de restinga e estuário (biodiversidade genética); atratividade cênica para atividades ecoturísticas; ausência de construções e áreas de reconhecido de valor histórico; elevada qualidade recreacional; ocorrência de pelo menos um atrativo cênico natural (estuário).

A praia Jóia do Atlântico - trecho 2: apresenta características similares a Jóia do Atlântico - trecho 1, contudo, difere do trecho 1 quanto aos serviços de regulação e suporte devido a ausência de refúgio e/ou berçário marinho e por possuir poucas áreas servindo como refúgio e/ou berçário terrestre (restinga). Quanto aos serviços de provisão difere do trecho 1, por possuir apenas uma fonte de recursos hídricos e pequena presença de recursos ornamentais (vegetais). Quanto aos serviços de informação e cultura, esta praia (trecho 2), difere do Jóia do Atlântico - trecho 1 por possuir media qualidade recreacional e ausência de atrativos naturais, além da sua própria faixa arenosa e marinha.

A praia Mar e Sol: é caracterizada pela ocorrência de vegetação em mais de $50 \%$ na pós-praia; ocorrência de terraços arenosos em mais de $50 \%$ de sua extensão; presença de terras úmidas em pelo menos de $50 \%$ do seu litoral; zona de surfe com até três linhas de arrebentação; ausência de recifes de corais e/ou bancos de arenitos; ocorrência de cordão-duna em mais de 50\% de seu litoral; presença de pelo menos uma área que pode servir como refúgio e/ou berçário marinho; presença de mais de uma área que pode servir como refúgio e/ou berçário terrestre; ocorrência de pelo menos uma atividade destinada à provisão de alimentos; presença de pelo menos uma atividade destinada à produção de alimentos em áreas cultivadas; presença de mais de uma fonte de recursos hídricos; presença de pelo menos uma fonte de recursos ornamentais; presença de restinga; atratividade cênica para atividades ecoturísticas; ausência de construções e áreas de reconhecido de valor histórico; qualidade recreacional média; ocorrência de pelo menos um atrativo cênico natural (estuário do Japará).

A praia de Japará: quanto aos serviços de regulação e suporte, apenas difere da praia Mar e Sol por possuir terras úmidas em mais de $50 \%$ de seu litoral e pela ocorrência de cordão-duna em menos de $50 \%$ de sua extensão. Os serviços de provisão, informação e cultura são similares à praia anterior.

A praia intitulada Fazenda de Osmar: é caracterizada pela ocorrência de vegetação em quase toda extensão na pós-praia; ocorrência de terraços arenosos em mais de $50 \%$ de sua extensão; presença de terras úmidas em menos de $50 \%$ do seu litoral; zona de surfe com até três linhas de arrebentação;

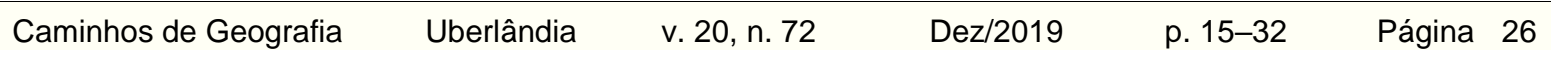


ausência de recifes de corais e/ou bancos de arenitos, atuando como proteção na ante-praia; ocorrência de cordão-duna em mais de 50\% de seu litoral; ausência de refúgio e/ou berçário marinho; ocorrência de pelo menos um refúgio e/ou berçário terrestre (restinga); ocorrência de pelo menos uma atividade destinada à provisão de alimentos (pesca); presença de pelo menos uma atividade destinada à produção de alimentos em áreas cultivadas (coco da baía); presença de fontes de recursos hídricos (lagoas e aquífero); presença de mais de uma fonte de recursos ornamentais (madeira morta e vegetação); presença de restinga e seus diversos recursos genéticos (biodiversidade); atratividade cênica para atividades ecoturísticas; ausência de construções e áreas de reconhecido de valor histórico; qualidade recreacional média; sem atrativo cênico natural, além da sua própria faixa arenosa e marinha.

A praia de São Domingos - trecho 1: é caracterizada pela ocorrência de vegetação em mais de $50 \%$ na pós-praia; ocorrência de terraços arenosos em mais de $50 \%$ de sua extensão; pequena ocorrência de terras úmidas; zona de surfe com até três linhas de arrebentação; ausência de recifes de corais e/ou bancos de arenitos, agindo como proteção na ante-praia; ocorrência de cordão-duna em mais de $50 \%$ de seu litoral; ocorrência de mais de uma área que pode servir como refúgio e/ou berçário terrestre/transicional; ocorrência de pelo menos uma atividade destinada à provisão de alimentos (pesca); presença de mais de uma atividade destinada à produção de alimentos em áreas cultivadas (coco da baía); presença de fontes de recursos hídricos (Rio Almada e aquíferos); presença de fontes de recursos ornamentais (madeira morta e vegetação); presença de restinga e manguezal (alta biodiversidade); pouca atratividade cênica para atividades ecoturísticas; ausência de construções e áreas de reconhecido de valor histórico; qualidade recreacional média; sem atrativo cênico natural, além da sua própria faixa arenosa e marinha.

A praia de São Domingos - trecho 2: difere da praia de São Domingos - trecho 1 apenas nos itens relacionados aos serviços de regulação/suporte e provisão, apresentando todos os itens relacionados aos serviços de informação e cultura similares. $\mathrm{O}$ trecho 2 é caracterizado pela ocorrência de vegetação em menos $50 \%$ na pós-praia; ocorrência de terraços arenosos em menos $50 \%$ de sua extensão; presença de terras úmidas em menos de $50 \%$ de seu litoral; zona de surfe com até três linhas de arrebentação; ausência de recifes de corais e/ou bancos de arenitos; ausência de cordão-duna; ausência de área que pode servir como refúgio e/ou berçário marinho; ocorrência de pelo menos um refúgio e/ou berçário terrestre (manguezal no Rio Almada); ocorrência de mais de uma atividade destinada à provisão de alimentos (pesca e mariscagem); não ocorrência de atividade destinada à produção de alimentos em áreas cultivadas; presença de pelo menos uma fonte de recursos hídricos; presença de mais de uma fonte de recursos ornamentais (madeira morta e vegetação) e; grande ocorrência de áreas antropizadas e sob forte processo de erosão costeira (Figura 4).

Figura 4 - Alta vulnerabilidade a erosão costeira, praia de São Domingos - trecho 2, Ilhéus.

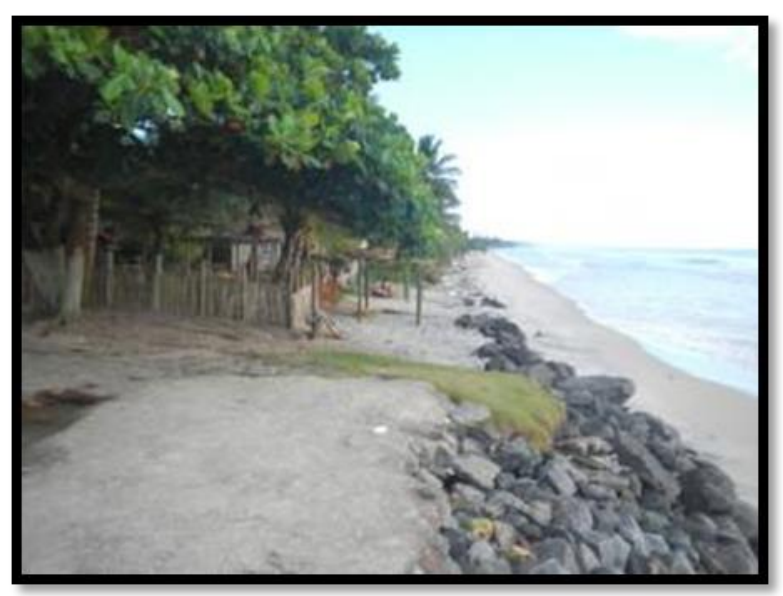

A praia de São Miguel: assim como a praia de São Domingos - trecho 2, apresenta vegetação em menos $50 \%$ na pós-praia; ocorrência de terraços arenosos em menos $50 \%$ de sua extensão; presença de terras úmidas em menos de $50 \%$ de seu litoral; zona de surfe com até três linhas de arrebentação; ausência de recifes de corais e/ou bancos de arenitos; ausência de cordão-duna; ausência de área que pode servir como refúgio e/ou berçário marinho; ocorrência de pelo menos um refúgio e/ou berçário terrestre (manguezal no Rio Almada); ocorrência de mais de uma atividade destinada à provisão de alimentos (pesca e mariscagem); não ocorrência de atividade destinada à produção de alimentos em

$\begin{array}{lllll}\text { Caminhos de Geografia } \quad \text { Uberlândia } & \text { v. 20, n. } 72 & \text { Dez/2019 } & \text { p. 15-32 } & \text { Página } 27\end{array}$


áreas cultivadas; presença de pelo menos uma fonte de recursos hídricos; presença de mais de uma fonte de recursos ornamentais (madeira morta e vegetação) e; grande ocorrência de áreas antropizadas e sob forte processo de erosão costeira. Mas destaca-se pela ocorrência de refúgio/berçário marinho, a foz (estuário) do Rio Almada (Figura 5).

Figura 5 - Foz do Rio Almada, praia de São Miguel, Ilhéus.

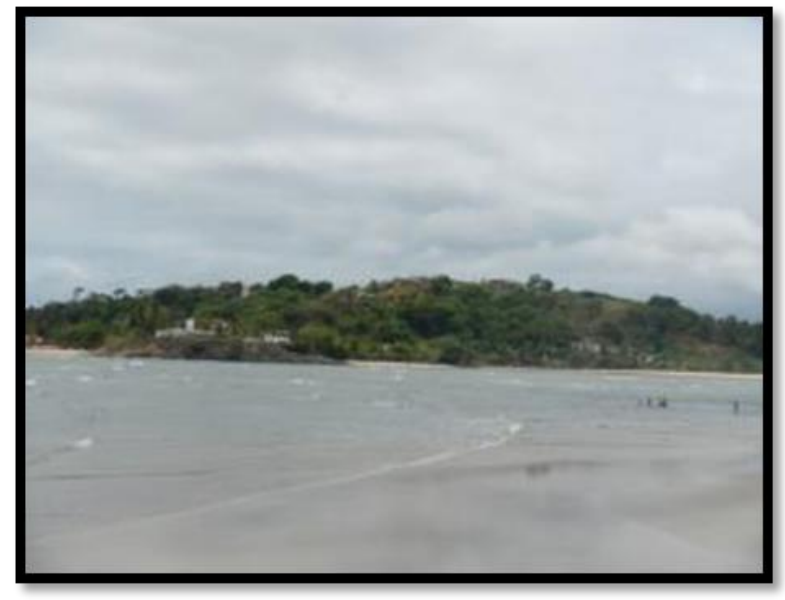

A Figura 6 apresenta a valoração dos serviços ecossistêmicos oferecidos pelas praias da APA da Lagoa Encantada/Rio Almada, através do qual observa-se que a maioria das praias apresenta bons índices de serviços ecossistêmicos, sendo maiores em Sargi (trecho 2), Ponta do Ramo e Mamoã (trecho 3), que possuem altos índices (Figura 7). A exceção é a praia de Ponta da Tulha (trecho 2), onde os serviços de suporte e regulação são baixos, o que acabou por repercutir na diminuição da oferta de serviços de provisão, informação e cultura.

A presença e manutenção dos serviços de regulação e/ou suporte na área alicerça a existência dos serviços de provisão, de informação, cultura e lazer, conforme também sinalizado por Santos e Silva (2012). Isto se deve a ocorrência de zona de surfe com até três linhas de arrebentação, vegetação na área de pós-praia, de cordão-duna, de terraços arenosos, de terras úmidas e manguezais e, por conseguinte, presença de área de refúgio/berçário marinho e terrestre, o que são responsáveis pela diminuição dos efeitos provocados pelos agentes erosivos, pelo equilíbrio térmico, pelo armazenamento de água e equilíbrio do nível estático do lençol, pela assimilação, depuração e transformação de poluentes, bem como pela manutenção da produtividade primária.

Analisando a zona costeira da APA Lagoa Encantada/Rio Almada, pode-se observar que todos os trechos litorâneos apresentam, associados à praia, em maior ou menor grau, serviços de controle e estocagem de água e de assimilação e reciclagem de nutrientes. Todavia, alguns trechos possuem concomitantemente as funções de berçário e refúgio para diversas espécies, além de serem fontes de produção (natural ou cultivada) de alimentos, recursos ornamentais e genéticos, a exemplo do Sargi - trecho 2, Ponta do Ramo, Mamoã - trecho 3, Ponta da Tulha - trecho 1, Paraíso do Atlântico, Jóia do Atlântico - trecho 1 , Mar e Sol, Japará, Fazenda de Osmar e São Domingos - trecho 1. Destaca-se que todos estes serviços estão diretamente ligados a presença dos ecossistemas de terras úmidas, manguezais e estuários.

Ressalta-se ainda que, fora os trechos de São Miguel e São Domingos - trecho 2, onde parte dos terraços arenosos marinhos foram impermeabilizados pelas construções antropogênicas, no restante das praias da APA Lagoa Encantada/Rio Almada ocorrem serviços de regulação associados à recarga de aquíferos, como também serviços de refúgio e berçário terrestre associados à preservação da vegetação de restinga sobre os terraços marinhos. Em alguns casos, a preservação deste ecossistema possibilita ainda a provisão de recursos ornamentais, produção de alimentos e serviços associados ao ecoturismo.

É necessário destacar também que a retirada da vegetação na pós-praia pela ocupação urbana (residencial e comercial) em São Miguel e São Domingos - trecho 2, provavelmente, atuou como catalizador no processo de erosão do cordão-duna e perda desta barreira natural de proteção a zona costeira adjacente. Nos trechos onde a vegetação natural está conservada, São Domingos - trecho 1 , Fazenda de Osmar, Japará e Mar e Sol, são providos os serviços de suporte associados à retenção de sedimentos na zona costeira adjacente e pós-praia, minimizando os impactos da erosão costeira neste litoral.

\begin{tabular}{llllll}
\hline Caminhos de Geografia & Uberlândia & v. 20, n. 72 & Dez/2019 & p. 15-32 & Página 28
\end{tabular}


Figura 6 - Valoração dos serviços ecossistêmicos oferecidos pelas praias da APA da Lagoa Encantada/Rio Almada.

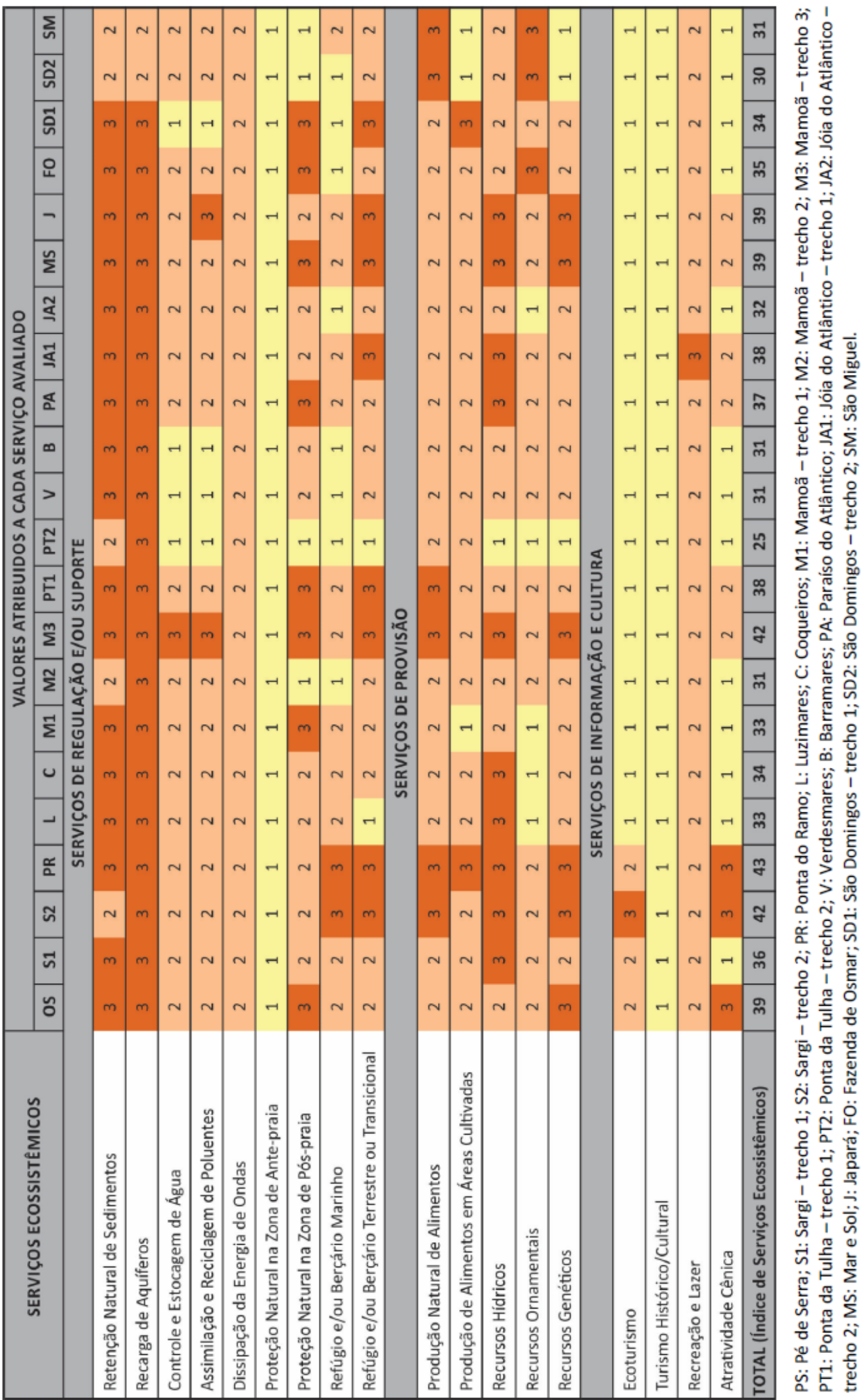


Figura 7 - Avaliação qualitativa dos serviços ecossistêmicos oferecidos pelas praias da APA da Lagoa Encantada/Rio Almada.

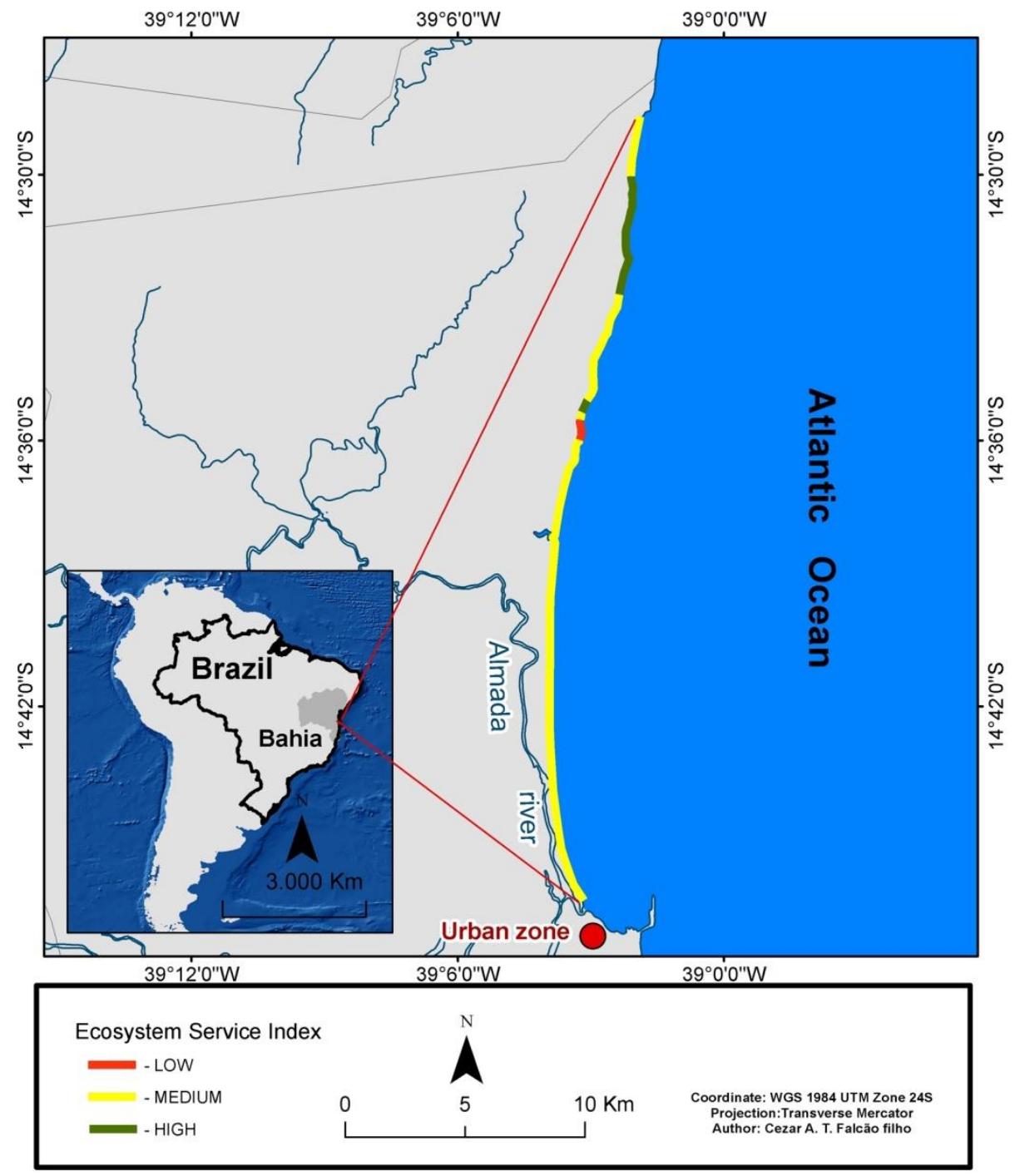

\section{CONSIDERAÇÕES FINAIS}

Os serviços ecossistêmicos ofertados pelas praias da APA Lagoa Encantada/Rio Almada e sua zona costeira adjacente (até o limite de $200 \mathrm{~m}$ da zona de pós-praia) foram avaliados qualitativamente e correlacionados com as atuais condições de uso e ocupação do solo deste trecho do litoral baiano. Esta análise demonstrou uma forte correlação entre as condições naturais e as modificações antropogênicas em andamento, ou seja, observa-se que quanto maior a concentração dos sistemas técnicos (infraestruturas urbanas, etc.) menor a variedade e qualidade dos serviços, tanto de regulação e/ou suporte como de provisão e de informação, cultura e lazer, como nas praias de São Miguel e São Domingos - trecho 2. Inversamente, as praias com pouco presença de sistemas técnicos e baixa ocupação humana, apresentaram serviços ecossistêmicos de alta qualidade e diversidade, com destaque para os serviços de regulação e suporte que por si só, permitem, através da sua manutenção, as bases para oferta dos serviços de provisão e os de informação, cultura e lazer.

Assim, este trabalho permitiu verificar a importância dos estudos de diagnóstico e valoração ecológica como subsídio a gestão de ambientes costeiros, evidenciando o comprometimento na oferta e qualidade dos serviços ecossistêmicos, em especial, nas áreas suburbanas e em processo de urbanização. Nos espaços ainda preservados, mas considerados vetores turísticos ou de urbanização, é premente a implantação de medidas que possam minimizar os impactos e auxiliar na manutenção dos serviços ecossistêmicos ofertados.

\begin{tabular}{lllll}
\hline Caminhos de Geografia $\quad$ Uberlândia & v. 20, n. $72 \quad$ Dez/2019 & p. 15-32 Página 30
\end{tabular}




\section{AGRADECIMENTOS}

Os autores agradecem ao Instituto Federal de Educação, Ciência e Tecnologia Baiano - Campus Uruçuca, pelo apoio durante as atividades de campo e ao Conselho Nacional de Desenvolvimento Científico e Tecnológico pela Bolsa de Produtividade em Pesquisa do segundo autor.

\section{REFERÊNCIAS}

ANDRADE, D.C.; ROMEIRO, A.R. Serviços ecossistêmicos e sua importância para o sistema econômico e o bem-estar humano. Campinas: IE/UNICAMP, n. 155. 2009.

BAHIA. Secretaria de Infraestrutura. Departamento de Infraestrutura de Transportes da Bahia. Tomo II, Volume 1, Estudo de Impacto Ambiental - EIA, Relatório de Impacto Ambiental - RIMA, para implantação do Porto Sul em Ilhéus. Salvador, 2011. 555 p.

BOCKSTAEL, N.A.; FREEMAN, A.M.; KOPP, R.J.; PORTNEY, P.R.; SMITH, V.K. On measuring economic values for nature - Environ. Science Technological, v. 34, p. 1384-1389, 2000.

https://doi.org/10.1021/es990673|

BRASIL. Lei 7.661, de 16 de maio de 1988. Publicada no Diário Oficial da União de 18 de maio de 1998.

CONSTANZA, R. Social Goals and the Valuation of Ecosystem Services. Ecosystems, v. 3, p. 4- 10, 2000. https://doi.org/10.1007/s100210000002

CONSTANZA, R. What is Ecological Economics? Ecological Economics, v. 1, p. 1-7, 1989. https://doi.org/10.1016/0921-8009(89)90020-7

COSTANZA, R., D'ARGE, R., DE GROOT, R.S., FARBER, S., GRASSO, M., HANNON, B., LIMBURG, K., NAEEM, S., O'NEILL, R.V., PARUELO, J., RASKIN, R.G., SUTTON, P., VAN DEN BELT, M., The value of the world's ecosystem services and natural capital. Nature, v., n. 387, p. 253-260, 1987. https://doi.org/10.1038/387253a0

CPRM. Programa Levantamentos Geológicos Básicos do Brasil. Carta Geológica de Itabuna 1: 100.000. Companhia de Pesquisa e Recursos Minerais, 1991.

DALY, H. E.; FARLEY, J. Ecological economics: principles and applications. Island Press: Washington, 2004. https://doi.org/10.1016/..ecolecon.2004.04.008

DE GROOT, R.S., WILSON, M.A.. BOUMANS, R.M.J. A typology for the classification, description, and valuation of ecosystem functions, goods and services. Ecological Economics, v., n. 41, p. 393-408, 2002. https://doi.org/10.1016/S0921-8009(02)00089-7

HEIN, L.; VAN KOPPEN, K.; DE GROOT, R.; VAN IERLAND, E.C. Spatial scales, stakeholders and the valuation of ecosystem service. Ecological Economics, v. 57, 209 - 228, 2006.

https://doi.org/10.1016/i.ecolecon.2005.04.005

INGÁ/CEMBA. Disponível em: http://www.srh.ba.gov.br. Acesso em: 05 de dezembro de 2009.

INMET/BRASIL (acesso em dezembro 2016), Instituto Nacional de Meteorologia. Normais climatológicas. Disponível em < http://www.inmet.gov.br/portal/index.php?r=clima/normaisClimatologicas>.

MA - MILLENNIUM ECOSYSTEM ASSESS MENT . Ecosystem and Human Well-Being: a framework for assessment. Washington, DC.: Island Press. 2003.

MATOS, J. E. R. Chuvas intensas na Bahia: equações e metodologias de regionalização. Salvador: EDUFBA, 2006. https://doi.org/10.3895/S1808-04482005000200009

MATTOS, K. M. da C.; MATTOS, K. M. da C.; MATTOS, A. Valoração econômica do meio ambiente dentro do contexto do desenvolvimento sustentável. Revista Gestão Industrial. v. 01 , n. 02 : pp. 105-117, 2005.

MERICO, L. F. K. Introdução à economia ecológica. Blumenau: FURB, 1996.

MMA - Ministério do Meio Ambiente, Ministério do Planejamento, Orçamento e Gestão. Projeto Orla:

manual de gestão. Brasília. 88p. 2006. Disponível em:

<https://www.mma.gov.br/estruturas/orla/_arquivos/11_04122008111238.pdf>. 
SACHS, I; VIEIRA, P. F. (org.). Rumo à ecossocioeconomia: teoria e prática do desenvolvimento. São Paulo: Cortez, 2007.

SANTOS, R. C.; SILVA, I. R. Serviços ecossistêmicos oferecidos pelas praias do município de Camaçari, Litoral Norte do Estado da Bahia, Brasil. Cadernos de Geociências, v. 9, n. 1, maio 2012. p. 47-56.

SOUZA FILHO, J.R.; SANTOS, R.C.; SILVA, I.R.; ELLIFF, C.I. Evaluation of recreational quality, carrying capacity and ecosystem services supplied by sandy beaches of the municipality of Camaçari, northern coast of Bahia, Brazil. Journal of Coastal Research, Special Issue No. 70, 2014a, p. 527-532. https://doi.org/10.2112/SI70-089.1

SOUZA FILHO, J. R.; SILVA, I. R.; BITTENCOURT, A.C.S.P. Qualidade recreacional das praias da APA Lagoa Encantada/Rio Almada, Litoral Sul do Estado da Bahia. Cadernos de Geociências, v. 11, n. 1-2, 2014b. p.21-35.

Recebido em: 15/02/2018

Aceito para publicação em: 27/11/2019 